\title{
Soil Fungistasis: Role of Volatile Inhibitors in Two Soils
}

\author{
By W. H. KO AND F. K. CHOW \\ Department of Plant Pathology, University of Hawaii, Beaumont Agricultural \\ Research Center, Hilo, Hawaii 96720, U.S.A.
}

(Received 28 June I977)

\begin{abstract}
Volatile inhibitors were detected in Conover loam and sandy loam soils by incubating spores on double layer cellophane over, but separated from, soil in a Petri dish. Spores of Exserohilum rostratum and Alternaria solani which were not inhibited by the volatile inhibitors did not germinate in soils. Three other inhibitor-sensitive fungi were not affected by the amount of volatile inhibitors emanated from $0.5 \mathrm{~g}$ of soils, but they failed to germinate when incubated in that amount of soil. Attempts to remove volatile inhibitors from soils by aeration did not increase spore germination. Results suggested that volatile inhibitors from these soils were of secondary importance and superimposed upon fungistasis caused mainly by nutrient deprivation.
\end{abstract}

\section{INTRODUCTION}

Ko \& Lockwood (1967) showed that fungal spores do not germinate in soil either because they cannot obtain sufficient nutrients for germination or because they lose nutrients from spores due to a diffusion stress in soil created by microbial activity. Hora \& Baker (1970) demonstrated the presence of a volatile inhibitor in certain alkaline soils, but its properties were different from those of widespread soil fungistasis (Ko \& Hora, 1972). The inhibitor was subsequently identified as ammonia (Ko, Hora \& Herlicska, 1974). Recently, volatile inhibitors were also detected in acid soils (Romine \& Baker, I973), although Bristow \& Lockwood (1975) failed to detect them in the Conover loam soil ( $\mathrm{pH} 6 \cdot 7)$ which has been extensively used by Lockwood and his associates in their fungistasis studies (Lockwood, 1977). By using a more sensitive method we were able to detect the volatile inhibitors in the Conover loam soil. The aim of the work reported in this paper was to compare the contribution of volatile inhibitors to fungistasis in this soil and in a Hawaiian sandy loam soil $(\mathrm{pH} 5 \cdot 9)$.

\section{METHODS}

Fungal spores. Conidia of Bipolaris maydis (Helminthosporium maydis), Bipolaris stenospila (H. stenospilum), Exserohilum rostratum $(H$. rostratum) and Alternaria alternata were obtained by growing each fungus under continuous fluorescent light for 7 days at $28^{\circ} \mathrm{C}$ on V-8 juice agar (Aragaki, 1964). Conidiation of Alternaria solani was induced by growing the fungus on V-8 juice agar at $28{ }^{\circ} \mathrm{C}$ for 3 days with light followed by 4 days incubation at $20^{\circ} \mathrm{C}$ (Aragaki, 1964). Bipolaris maydis, B. stenospila, E. rostratum and $A$. solani were supplied by $\mathrm{M}$. Aragaki, University of Hawaii.

Assay methods. Difco Bacto-Noble agar discs $(20 \times 3.5 \mathrm{~mm})$, Bacto-purified agar discs $(20 \times 3.5 \mathrm{~mm})$, and pieces of double layer non-coated cellophane $(30 \times 15 \mathrm{~mm})$ were used to support spores for germination above the soil surface. Agar discs were washed before use in running tap water for $3 \mathrm{~h}$ at a rate of $\mathrm{I} 2000 \mathrm{ml} \mathrm{min}^{-1}$ to remove nutrients as suggested by Romine \& Baker (1973). Washed agar discs remained sterile after incubation on V-8 juice agar at $24^{\circ} \mathrm{C}$ for 7 days. Small pieces $(30 \times 15 \mathrm{~mm}$ ) of cellophane were washed once in boiling water for $5 \mathrm{~min}$ and autoclaved in distilled water for $15 \mathrm{~min}$. Individual agar discs or pieces of double layer cellophane were placed on the inside surface of a sterile lid of a Petri dish base (100 $\times 20 \mathrm{~mm}$ ) which contained 50 or $0.5 \mathrm{~g}$ of air-dried soil remoistened to $70 \%$ water-holding capacity. Agar discs and 
Table I. Comparison of three methods for detecting volatile inhibitors from soil using Bipolaris maydis as the test fungus

Results are the average of experiments done in duplicate and repeated once.

\begin{tabular}{lccc} 
& \multicolumn{3}{c}{ Spore germination (\%) } \\
Soil tested & Cellophane & $\begin{array}{c}\text { Washed } \\
\text { purified agar }\end{array}$ & Noble agar \\
Conover loam & I 8 & $\mathbf{8 2}$ & 95 \\
Sandy loam & 2I & $\mathbf{8 2}$ & 96 \\
Water (control) & 95 & 96 & 93
\end{tabular}

Table 2. Spore germination in soil and on cellophane discs placed above soil

\begin{tabular}{|c|c|c|c|c|c|}
\hline \multirow[b]{3}{*}{ Fungus } & \multicolumn{5}{|c|}{ Spore germination $(\%)$} \\
\hline & \multirow{2}{*}{$\begin{array}{l}\text { Distilled } \\
\text { water }\end{array}$} & \multicolumn{2}{|c|}{ Conover loam } & \multicolumn{2}{|c|}{ Sandy loam } \\
\hline & & Above soil* & In soil $\dagger$ & Above soil* & In soili \\
\hline xserohilum rostratum & 94 & 99 & 5 & 98 & 25 \\
\hline Alternaria solani & 99 & 92 & 14 & 96 & 26 \\
\hline A. alternata & 99 & 96 & $3 \mathrm{I}$ & 95 & I \\
\hline Bipolaris stenospila & 85 & 97 & 28 & 98 & 8 \\
\hline B. maydis & 78 & 70 & 4 & 74 & $2 \mathrm{I}$ \\
\hline
\end{tabular}

* Spore germination was tested on pieces of double layer cellophane placed on the inside surface of a sterile lid of a Petri dish base which contained $50 \mathrm{~g}$ of soil for E. rostratum and A. solani, or 0.5 $\mathrm{g}$ of soil for the other fungi.

$\dagger$ Germination of spores in $0.5 \mathrm{~g}$ of soil in a Petri dish was determined after incubation for $6 \mathrm{~h}$ at $24{ }^{\circ} \mathrm{C}$.

\section{Table 3. Effect of aeration with moist air on germination of fungal spores in $0.5 \mathrm{~g}$ of soil}

Results are the average of experiments done in duplicate and repeated once.

\begin{tabular}{|c|c|c|c|c|}
\hline \multirow[b]{3}{*}{ Fungus } & \multicolumn{4}{|c|}{ Spore germination $(\%)$} \\
\hline & \multicolumn{2}{|c|}{ Conover loam } & \multicolumn{2}{|c|}{ Sandy loam } \\
\hline & $\begin{array}{c}\text { With } \\
\text { aeration }\end{array}$ & $\begin{array}{l}\text { Without } \\
\text { aeration }\end{array}$ & $\begin{array}{l}\text { With } \\
\text { aeration }\end{array}$ & $\begin{array}{l}\text { Without } \\
\text { aeration }\end{array}$ \\
\hline Bipolaris maydis & 6 & 2 & 4 & I 2 \\
\hline Exserohilum rostratum & 34 & 37 & 14 & 15 \\
\hline
\end{tabular}

cellophane were 8 to $10 \mathrm{~mm}$ above the soil surface. After $\mathrm{I} 2 \mathrm{~h}$ pre-incubation at $24{ }^{\circ} \mathrm{C}$, spores in distilled water were transferred with a disposable pipette on to agar discs or cellophane and incubated for $6 \mathrm{~h}$. Agar dises and cellophane exposed above distilled water in a Petri dish were used as controls.

For testing spore germination directly in soil, one drop (about $0.035 \mathrm{ml}$ ) of spore suspension $\left(12 \times 10^{\text {I }} \mathrm{ml}^{-1}\right)$ was added to $0.5 \mathrm{~g}$ of soil in a Petri dish. After $6 \mathrm{~h}$ incubation, one drop of rose bengal solution was added to soil transferred to a test tube. Germlings and spores were separated from soil particles by shaking the soil with $2 \mathrm{ml}$ of a solution of $5.5 \mathrm{M}-\mathrm{NaOH}$ and $0.5 \mathrm{M}-\mathrm{NaCl}$. Three drops of the resulting soil suspension were placed on a slide and the percentage spore germination was determined.

To study the effect of aeration on spore germination in soil, $0.5 \mathrm{~g}$ of soil inoculated with spores was placed in a capped polyethylene vial $(33 \times 53 \mathrm{~mm})$. An inlet hole and an outlet hole were made at opposite sides of opposite ends of the vial. Moist air was continuously pumped in through the inlet hole at a rate of 800 to $1400 \mathrm{ml} \mathrm{min}{ }^{-1}$. Spore germination was determined as described above after $6 \mathrm{~h}$.

The percentage spore germination was based on 200 spores counted for each treatment. All experiments were done in duplicate, and repeated at least once. Results presented are averages of the experiments. 


\section{RESULTS}

With agar disc methods, the volatile inhibitors were barely detectable but when the cellophane method was used, spore germination of B. maydis decreased from $95 \%$ in the control to $\mathrm{I} 8$ to $2 \mathrm{I} \%$ above both soils (Table I). Pre-incubation of cellophane over soils did not increase the sensitivity of the method. Spore germination of $B$. maydis decreased from $89 \%$ in the control to 33 to $34 \%$ with pre-incubation and 30 to $35 \%$ without pre-incubation above both soils. Therefore, subsequent experiments were done without pre-incubation.

Although spore germination of $E$. rostratum and $A$. solani was not inhibited by volatile inhibitors emanated from $50 \mathrm{~g}$ of soils, both fungi germinated poorly in Conover loam and sandy loam soils (Table 2). Spore germination of $A$. alternata, B. stenospila and B. maydis was inhibited by the inhibitors evolved from $50 \mathrm{~g}$ of soils, but was not affected by the amount of inhibitors from $0.5 \mathrm{~g}$ of the same soils. When tested directly in $0.5 \mathrm{~g}$ of soils, spore germination of these three fungi was still inhibited.

The role of volatile inhibitors in soil fungistasis was further studied by germinating spores of $B$. maydis and E. rostratum in soils continuously aerated with moist air. Inhibition of spore germination in soil was not reduced by this treatment (Table 3 ).

\section{DISCUSSION}

The cellophane method appears to be more sensitive than the agar disc method for assaying volatile inhibitors in soil. This is probably due to the absence of available nutrients in the cellophane. For the same reason the cellophane method is most suitable for fungi which do not require nutrients for germination (nutrient independent) such as those used in this study. This method may be applicable also to those fungi which require nutrients for germination (nutrient dependent) if nutrients were added to the spore suspension. Its advantage over the washed agar disc methods is the ability to standardize the amount of nutrients used.

If volatile inhibitors are the main cause of soil fungistasis, one would expect those fungi which are not sensitive to the inhibitors to germinate freely in soil. Our results showed that $E$. rostratum and $A$. solani which were not inhibited by the volatile inhibitors, were still unable to germinate in the soils tested. The other three fungi which were sensitive to the volatile inhibitors but were not affected by the amount evolved from $0.5 \mathrm{~g}$ of soil, also failed to germinate directly in that amount of soil. Moreover, extensive aeration which was presumed to remove volatile inhibitors, did not increase spore germination in soils. Bristow \& Lockwood (I975) also passed moist air over soil for extended periods of time and observed no germination of Cochliobolus victoriae conidia, of sclerotia of Sclerotium rolfsii nor of spores of indigenous soil fungi. This contrasts with a report of annulment of fungistasis in Australian soil by a similar treatment (Smith, 1973). Soil fungistasis in Conover loam soil is caused primarily by nutrient deprivation (Ko \& Lockwood, I967; Bristow \& Lockwood, 1975). For those fungi sensitive to them, volatile inhibitors appear to be a secondary factor superimposed upon fungistasis caused mainly by nutrient deprivation.

Journal Series Paper No. 2 I 60 of the Hawaii Agricultural Experiment Station. Supported in part by a grant from the McIntire-Stennis Cooperative Forestry Research Program. We thank J. L. Lockwood for the gift of Conover loam soil. 


\section{REFERENCES}

ARAGAK1, M. (1964). Relation of radiation and temperature to the sporulation of Alternaria tomato and other fungi. Phytopathology 54, 565-569.

Bristow, P. R. \& Lockwood, J. L. (1975). Soil fungistasis: role of the microbial nutrient sink and of fungistatic substances in two soils. Journal of General Microbiology 9o, 147-156.

Hora, T. S. \& BAKER, R. (1970). A volatile factor in soil fungistasis. Nature, London 225, 107 I-1072.

Ko, W. H. \& HorA, F. K. (1972). The nature of a volatile inhibitor from certain alkaline soils. Phytopathology 62, 573-575.

Ko, W. H. \& Lockwood, J. L. (1967). Soil fungi- stasis: relation to fungal spore nutrition. Phytopathology 57, 894-901.

Ko, W. H., Hora, F. K. \& Herlicska, E. (1974). Isolation and identification of a volatile fungistatic substance from alkaline soil. Phytopathology 64, 1398-I 400 .

LocKwood, J. L. (1977). Fungistasis in soil. Biological Reviews 52, I-43.

Romine, M. \& BAKer, R. (1973). Soil fungistasis: evidence for an inhibitory factor. Phytopathology 63, 756-759.

Smith, A. M. (1973). Ethylene as a cause of soil fungistasis. Nature, London 246, 3I I-3 I3. 